\title{
Potential Use of Sicilian Landraces in Biofortification of Modern Durum Wheat Varieties: Evaluation of Caryopsis Micronutrient Concentrations
}

\author{
F. Sciacca ${ }^{1}$, M. Allegra ${ }^{1}$, S. Licciardello ${ }^{1}$, G. Roccuzzo ${ }^{1}$, B. Torrisi ${ }^{1}$, N. Virzì ${ }^{1}$, \\ M. BRAMBILLA ${ }^{2 *}$, E. ROMANO ${ }^{2}$ and M. PALUMBO ${ }^{1}$ \\ ${ }^{1}$ Consiglio per la ricerca in agricoltura e l'analisi dell'economia agraria (CREA), \\ Centro di ricerca Cerealicoltura e Colture Industriali, Laboratorio di Acireale. \\ Corso Savoia, 190 - 95024 Acireale (Catania), Italy \\ ${ }^{2}$ Consiglio per la ricerca in agricoltura e l'analisi dell'economia agraria (CREA), \\ Centro di ricerca Ingegneria e Trasformazioni agroalimentari, sede di Treviglio. \\ Via Milano, 43 - 24047 Treviglio (Bergamo), Italy \\ (Received 29 March 2017; Accepted 5 May 2017; \\ Communicated by F. Békés)
}

\begin{abstract}
The selection process has caused modern durum wheat cultivars to achieve higher yields with different protein quality but also to have low micronutrient amounts. In order to evaluate the suitability of germplasm for the recovery of such nutrient content, macro- and microelements concentrations in twelve ancient Sicilian durum wheat landraces and in three modern cultivars were compared. According to the results, the substantial differences in macro- and micro-element concentrations between the two groups of wheat genotypes suggest ancient Sicilian landraces can effectively represent a suitable genetic material for biofortification plans of micronutrients in modern varieties.
\end{abstract}

Keywords: Triticum turgidum, biodiversity, bioactive compounds, mineral concentration

\section{Introduction}

The strategies of genetic improvement taken during the past were aimed at reducing the interaction of genotype with the environment resulting in the gradual replacement of durum wheat (Triticum turgidum ssp. durum) old populations (Thomas et al. 2012) with modern varieties having higher yields but lower mineral concentration (Zhao et al. 2009). Durum wheat major use is the manufacturing of pasta and other traditional products (Shewry 2009). Its end-use value relies on grain protein concentration and composition (Shewry and Halford 2002) that had been targeted by breeders (Shewry 2009) together with crop responsiveness to growing conditions as well as climate change (De Vita et al. 2010; Semenov et al. 2014).

Mineral concentration in wheat caryopses (with particular reference to microelements like $\mathrm{Zn}$ and $\mathrm{Fe}$ ) deserves attention, too: the dietary deficiency of essential micronutrients

\footnotetext{
*Corresponding Author: E-mail: massimo.brambilla@crea.gov.it; Phone: +39 036349603
} 
(the so-called "hidden hunger") has been affecting about three billion people worldwide (IFPRI 2014) and is more widespread than poor dietary quality and low energy intake (Stewart et al. 2009). At the same time, countries with high incidence of micronutrient deficiencies are actually relying on cereal-based foods as main component of the daily ration (Cakmak et al. 2010).

Increasing the total amounts and the bioavailabilities of $\mathrm{Zn}$ and $\mathrm{Fe}$ in food crops is the big challenge: in developing countries, cereal grains have been reported to be the primary source of Fe and $\mathrm{Zn}$ (Welch and Graham 1999) without, however, any satisfaction of people mineral requirements given the constant excretion such minerals undergo with the human biological functions.

Durum wheat represents an important source of many nutrients, including dietary fiber, vitamins and minerals (Zn, Fe, Mg and Se) (Lafiandra et al. 2014; Panatta 1997). Fe and $\mathrm{Zn}$ are both essential minerals for humans: Fe is a so-called type I nutrient (physiologic nutrient) while $\mathrm{Zn}$ is a type II one, meaning that it does not have any identifiable 'storage' compartment where it can be mobilized from (Golden 2004) so that, in case of inadequate intake, without regular supply cells enter a state of deficiency and stop their growth (Lowe et al. 2009). More in detail, iron is essential for the regulation of cellular growth and differentiation and for haemoglobin production (Dallman 1987). Its deficiency results in: i) children mental and psychomotor development decrease, ii) increase in both morbidity and mortality of mother and child at childbirth, iii) decrease in work performance and resistance to infection (Scrimshaw 1984; Hercberg et al. 1987; Lozoff et al. 1991). Zinc plays an important role in embryogenesis, gene expression as well as carbohydrates, lipids, proteins and nucleic acids synthesis and degradation (Nishi 1996; Sandström 1997).

Plant breeding to improve the nutritional quality of foods is a functional approach being used to improve the nutrient content of varieties of staple crops and in particular of durum wheat (Cakmak et al. 2010). Following the genetic effects wheat grain micronutrient and protein contents are subjected to (Gomez-Becerra et al. 2010a, 2010b), genetic biofortification plans aimed at producing modern durum wheat cultivars with improved concentration and bioavailability of $\mathrm{Zn}$ and Fe could greatly reduce micronutrient malnutrition (Altieri 2004; Zhao et al. 2009; Velu et al. 2014). Wild relatives, primitive wheats and landraces of spring wheat are the most promising sources for the development of wheat cultivars with increased micronutrient contents and bread making quality (Xu et al. 2011). Nonetheless, the milling process itself actually removes many minerals highly concentrated in kernel's teguments: this strongly influences durum wheat derived products physico-chemical properties and micronutrient bioavailability for the end users (Poblaciones et al. 2014; Padalino et al. 2014).

Up to now Sicilian landraces have been mainly studied with reference to the bio-agronomic, genetic, biochemical and technological characteristics (Boggini et al. 1990; Sciacca et al. 2003; Palumbo et al. 2008, 2013; Gallo et al. 2010; Mastromatteo et al. 2014; Sciacca et al. 2014), but at the moment, few information is available on their micronutrient composition compared to modern ones. In this work, caryopsis micronutrient concentrations of Sicilian old landraces and modern cultivars of durum wheat were in- 
vestigated with the ultimate aim of providing useful information about their suitability in genetic biofortification plans aimed at increasing wheat-derived products nutritional value.

\section{Material and Methods}

In this experimental study 12 durum wheat old Sicilian landraces (Biancuccia, Bivona, Castiglione, Ciciredda, Cotrone, Duro Lucano, Farro Lungo, Gioia, Regina, Ruscia, Sammartinara, Timilia) were compared with 3 modern cultivars widely grown in Italy (Duilio, Iride and Simeto). Field trials were carried out during the three-year period 20122014 at the CREA experimental farm placed in Libertinia (Catania, Italy - Lat. $37.54172^{\circ}$ Lon. $14.58462^{\circ}$ ), setting up $10 \mathrm{~m}^{2}$ plots, fertilized with $36 \mathrm{~kg} \mathrm{ha}^{-1}$ of $\mathrm{N}$ and $92 \mathrm{~kg} \mathrm{ha}^{-1}$ of $\mathrm{P}$ in pre-sowing followed by $54 \mathrm{~kg} \mathrm{ha}^{-1}$ of $\mathrm{N}$ in post emergence. All genotypes were sown in a complete randomized block design, without microelement fertilization.

At full ripening, the harvested caryopses underwent macro- (N, P, K and $\mathrm{Ca}$ ) and micro-element (Fe, $\mathrm{Zn}, \mathrm{Mn}, \mathrm{Cu}$ and $\mathrm{Sr}$ ) concentrations determination. Caryopses were milled and the obtained wholemeal semolina was dried in oven at $105{ }^{\circ} \mathrm{C}$ before weighing. Macro- and micro-elements concentrations were measured as follows:

- Total N: an aliquot of $0.5 \mathrm{~g}$ of dried wholemeal semolina was used for the determination of the content by micro-Kjeldahl method (AOAC 2010) with an automatic instrument (Büchi Distillation Unit K370, C).

- P, K, Fe, Zn, Mn, Cu, Li and Sr: an aliquot of $1 \mathrm{~g}$ of dried wholemeal semolina underwent muffle furnace complete incineration at $550{ }^{\circ} \mathrm{C}$. The ashes were afterwards dissolved in $100 \mathrm{~mL}$ of $0.16 \mathrm{~mol} \mathrm{~L}^{-1} \mathrm{HNO}_{3}$ ultra-pure water solution and analysed by Inductively Coupled Plasma - Optical Emission Spectrometry (ICP-OES, OPTIMA 2000DV, Perkin Elmer, Italy).

- $\mathrm{Ca}$ and Mg: $3 \mathrm{~g}$ of dried powder were completely incinerated at $550{ }^{\circ} \mathrm{C}$. The ashes were dissolved in $50 \mathrm{~mL}$ of $0.16 \mathrm{~mol} \mathrm{~L}^{-1} \mathrm{HNO}_{3}$ ultra-pure water solution and analysed by ICP-OES.

To increase the knowledge attained from the considered variables and, according to them, discriminate as much as differences as possible all data underwent $t$-test and multivariate processing with " $R$ " statistical software (R Development Core Team 2008) by means of Principal Components Analysis (PCA), followed by cluster analysis (Ward's method) carried out on standardized data (Todeschini 1988). Such processing was performed at first on the average nutrient concentrations of all the mineral elements recorded during the three years of testing, successively it was repeated considering only the elements that the previous processing pointed out to be the most influencing ones. 
The quality of the clustering was also validated by the analysis of the Silhouette values $-S_{(i)}$ (eq. 1) that, ranging from -1 to +1 represent the tightness of the data points within a cluster and the separation between different clusters in a given model (Rousseeuw 1987). They are computed as:

$$
S_{(i)}=\frac{b_{(i)}-a_{(i)}}{\max \left[a_{(i)}, b_{(i)}\right]}
$$

where: " $a_{(i)}$ " is the average Euclidean distance between data point " $i$ " and other data points in the cluster A, " $b_{(i)}$ " is the average Euclidian distance between " $i$ " and the points in the second closest cluster. Silhouette values close to zero mean that the data points have similar distance to two clusters. Positive values mean that data are closer to one cluster than to the second nearest one. Negative values indicate potential misclassification. The overall Silhouette width $-S_{(k)}$, which is the average $S_{(i)}$ over the whole dataset at varying of the number of the clusters gives a global measure of the quality of a clustering: the higher the value, the most probable is the $k$ number of clusters in the dataset. The results of the Ward clustering have therefore been validated calculating the silhouette widths for $k=2-5$ clusters for both the datasets.

\section{Results}

Table 1 reports the macro- and the micro-element average concentrations measured in the caryopses. The highest element concentrations found among all the samples were 33,600 $\mathrm{mg} \mathrm{kg}^{-1}$ for $\mathrm{N}$ and 4,950 $\mathrm{mg} \mathrm{kg}^{-1}$ for $\mathrm{P}$ both found in the genotype Farro lungo; 5,220 mg $\mathrm{kg}^{-1}$ for K in Cotrone; $682.8 \mathrm{mg} \mathrm{kg}^{-1}$ for Ca in Timilia; $98.1 \mathrm{mg} \mathrm{kg}^{-1}$ for Fe in Biancuccia; $61.4 \mathrm{mg} \mathrm{kg}^{-1}$ for Zn in Duro Luсапо; $57.4 \mathrm{mg} \mathrm{kg}^{-1}$ for $\mathrm{Mn}$ in Biancuccia; $25.9 \mathrm{mg} \mathrm{kg}^{-1}$ for $\mathrm{Cu}$ in Duilio and $10.8 \mathrm{mg} \mathrm{kg}^{-1}$ for $\mathrm{Sr}$ in Ciciredda.

Among the landraces showing the highest grain-Fe concentration $\left(74.4 \mathrm{mg} \mathrm{kg}^{-1}\right.$ in Biancuccia, $55.4 \mathrm{mg} \mathrm{kg}^{-1}$ in Farro Lungo, $53.6 \mathrm{mg} \mathrm{kg}^{-1}$ in Duro Lucano), Biancuccia was

Table 1. Macro- and micro-elements average concentration ( $\mathrm{mg} \mathrm{kg}^{-1} \mathrm{~d} . \mathrm{m}$.) and features in wheat caryopses

\begin{tabular}{|c|c|c|c|c|}
\hline & & Sicilian landraces & Modern cultivars & $t$-test sig. \\
\hline \multirow{4}{*}{ Macro-elements } & $\mathrm{N}$ & $26709 \pm 4949.5$ & $21941 \pm 2815.7$ & $* * *$ \\
\cline { 2 - 5 } & $\mathrm{P}$ & $4142 \pm 300.7$ & $3307 \pm 243.5$ & $* * *$ \\
\cline { 2 - 5 } & $\mathrm{K}$ & $3411 \pm 952.4$ & $2932 \pm 773.7$ & $* * *$ \\
\cline { 2 - 5 } & $\mathrm{Ca}$ & $509 \pm 62.8$ & $488 \pm 112.2$ & $*$ NS \\
\cline { 2 - 5 } & $\mathrm{Fe}$ & $52.04 \pm 6.6$ & $39.52 \pm 9.0$ & $* * *$ \\
\cline { 2 - 5 } & $\mathrm{Zn}$ & $44.38 \pm 4.7$ & $36.70 \pm 4.2$ & $* *$ \\
\cline { 2 - 5 } & $\mathrm{Mn}$ & $44.40 \pm 1.6$ & $32.17 \pm 4.7$ & $*$ \\
\cline { 2 - 5 } & $\mathrm{Cu}$ & $8.86 \pm 5.0$ & $9.87 \pm 6.8$ & $* * *$ \\
\hline
\end{tabular}

Notes: Data are expressed as arithmetic mean \pm standard deviation of the twelve genotypes per group. NS $=$ not significant; ${ }^{*} p<0.05 ; * * * p<0.001$. 
found to have the highest Mn concentration (52.8 $\mathrm{mg} \mathrm{kg}^{-1}$ ) and a high $\mathrm{Zn}$ concentration (46.0 $\left.\mathrm{mg} \mathrm{kg}^{-1}\right)$, while Castiglione recorded the highest $\mathrm{Cu}$ concentration $\left(7.73 \mathrm{mg} \mathrm{kg}^{-1}\right)$.

On the other side, among modern varieties, Simeto was the one with the highest grainFe concentration (42.5 $\mathrm{mg} \mathrm{kg}^{-1}$ ) but with low $\mathrm{Zn}$ concentration $\left(36.3 \mathrm{mg} \mathrm{kg}^{-1}\right)$, while Duilio had the highest concentration of $\mathrm{Zn}\left(40.6 \mathrm{mg} \mathrm{kg}^{-1}\right), \mathrm{Mn}\left(36.8 \mathrm{mg} \mathrm{kg}^{-1}\right), \mathrm{Cu}(10.4$ $\left.\mathrm{mg} \mathrm{kg}^{-1}\right)$ and $\mathrm{Sr}\left(5.0 \mathrm{mg} \mathrm{kg}^{-1}\right)$. The $t$-test carried out between Sicilian landraces and modern cultivars, showed statistical significance $(p<0.001)$ for all the macro-elements with exception for $\mathrm{Ca}$. With reference to micro-elements, the same test pointed out statistical significance between the two datasets for all elements: such significance turned out to be at $p<0.001$ with exception for $\mathrm{Cu}$ whose significance is at $p<0.05$ level.

The output of the PCA carried out on the dataset of the average nutrient concentrations recorded in the 2012-2014 period is represented by Fig. 1: such biplot accounts for $63.7 \%$ of overall explained variance and it shows the complete view of the vectors of all the considered elements pointing out how they affect the discrimination between modern varieties and landraces (dashed closed lines).

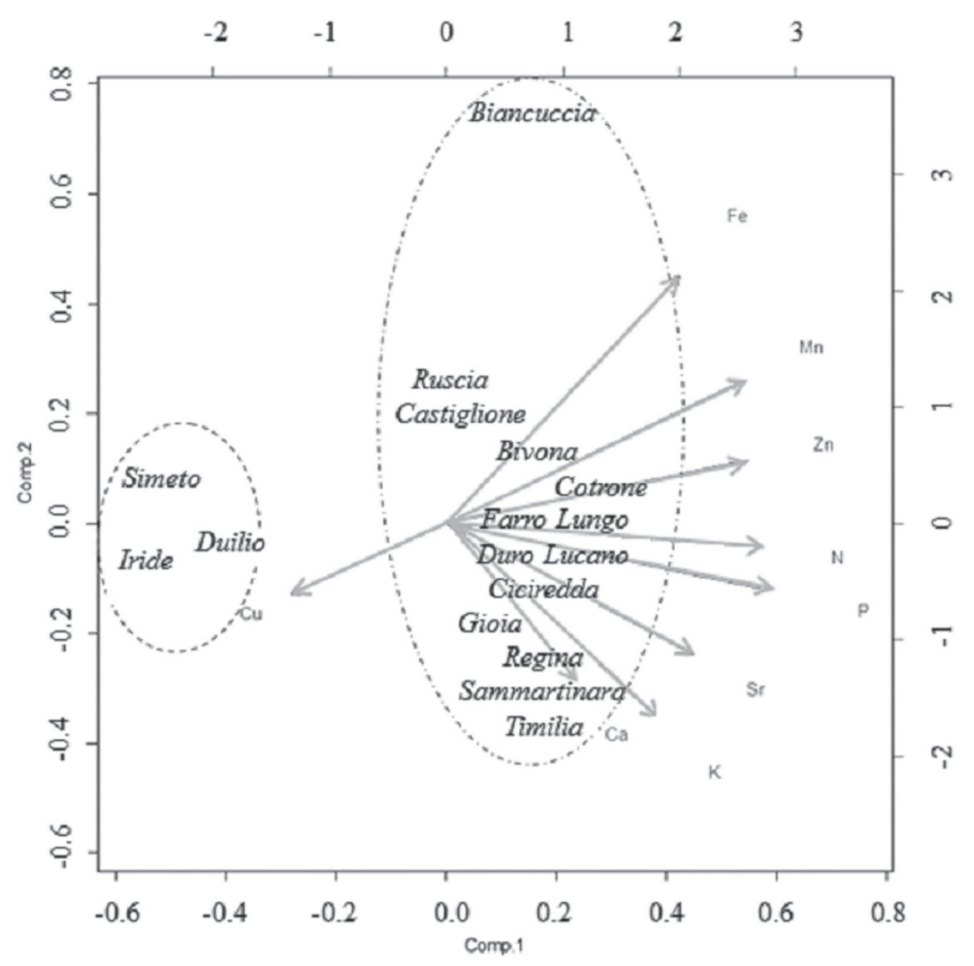

Figure 1. Biplot of the PCA representing the distribution of wheat genotypes based on the average nutrient concentrations of the three-year period 2012-2014 (x-axis and y-axis represent PC1 and PC2 scores, top and the right axes refer to scaled loadings and are meant for interpreting the arrows depicting the variables in the plot) 
The most significant loadings on the first component are the concentration of $\mathrm{P}(0.43)$, $\mathrm{N}(0.41), \mathrm{Zn}(0.39)$ and $\mathrm{Mn}(0.38)$, while those mainly affecting the second principal component are the concentrations of $\mathrm{Fe}(0.58), \mathrm{K}(-0.47) \mathrm{Ca}(-0.40)$ and $\mathrm{Mn}(0.33)$.

The dendrogram of the resulting cluster analysis (Fig. 2), confirmed the above-mentioned dissimilarities between modern varieties and landraces of this study when the dendrogram is cut at the linkage distance of 6 .

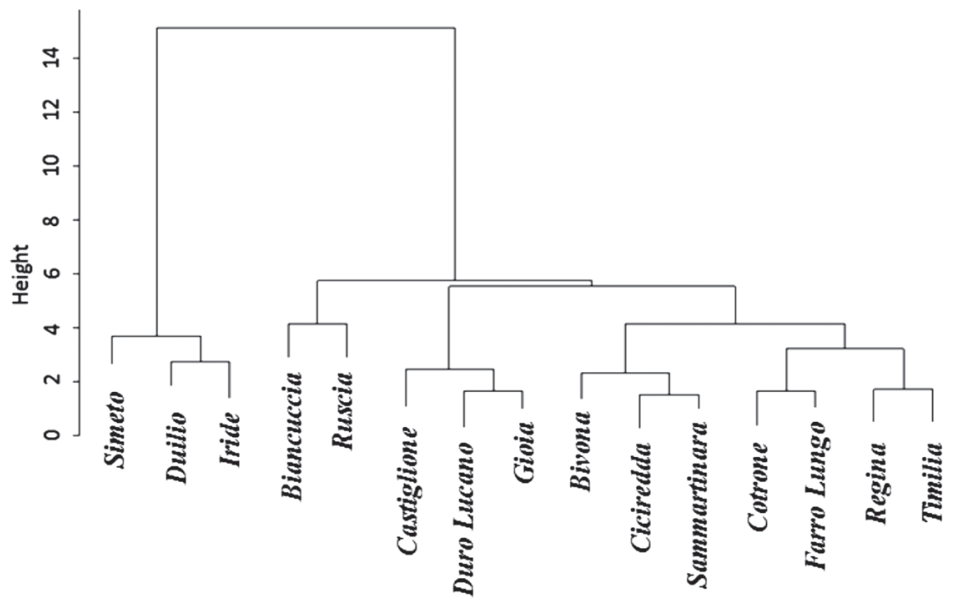

Figure 2. Dendrogram of the cluster analysis based on the average nutrient concentrations of the three-year period 2012-2014

The silhouette method identified two clusters as the most probable estimate: the average silhouette widths reported in Table 2 (left column) show how the most probable number of cluster is two according to the eigenvalues of all the considered elements.

Table 2. Average silhouette widths for the considered dendrograms

\begin{tabular}{|c|c|c|}
\hline \multirow{2}{*}{ Number of clusters } & \multicolumn{2}{|c|}{ Clustering factors } \\
\cline { 2 - 3 } & Macro- and micro-nutrient concentrations & Fe, Mn, Zn \\
\hline 2 & 0.415 & 0.312 \\
\hline 3 & 0.296 & 0.273 \\
\hline 4 & 0.262 & 0.229 \\
\hline 5 & 0.200 & 0.180 \\
\hline
\end{tabular}

The PCA performed on the data set of the values of concentration of $\mathrm{Fe}, \mathrm{Zn}$ and $\mathrm{Mn}$ in kernels in the three considered years, resulted in a biplot (Fig. 3) explaining $73.5 \%$ of the overall variability. In this case, the most significant loadings of the first component are those of zinc of 2013 (labelled $\mathrm{Zn13}=-0.39)$, iron of $2012(\mathrm{Fe} 12=-0.38)$ and manganese of all three years $(M n 12=-0.38, M n 13=-0.33, M n 14=-0.37)$, while the second 


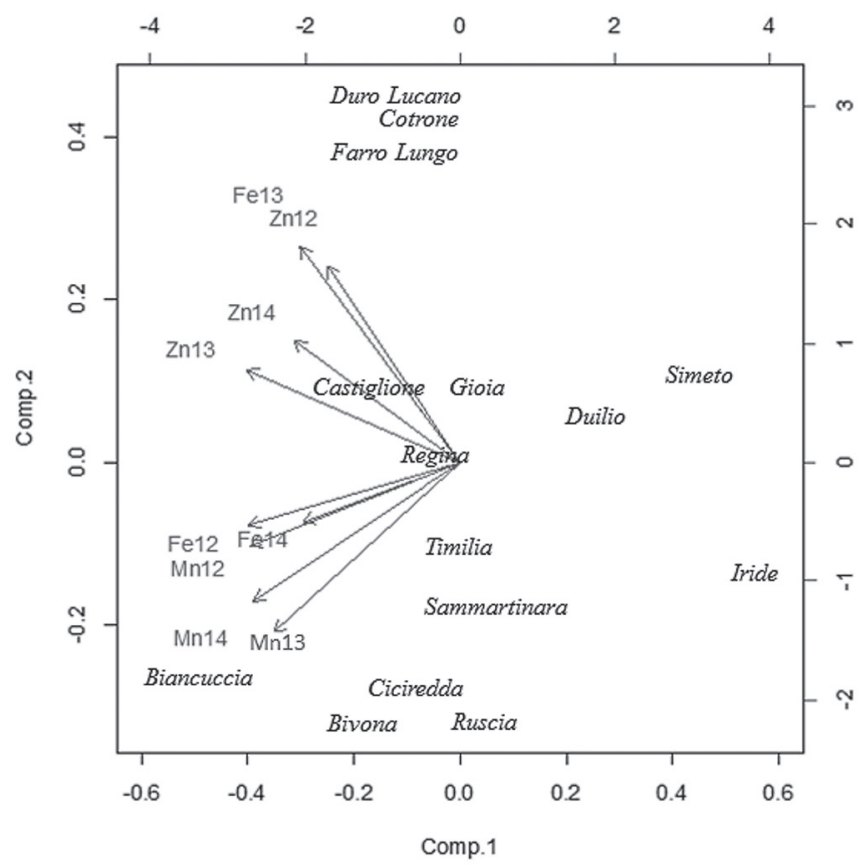

Figure 3. Biplot of the PCA representing the distribution of the studied genotypes based on the concentrations of iron, zinc and manganese in the kernels during the three years of experiment (x-axis and $y$-axis represent PC1 and PC2 scores, top and the right axes refer to scaled loadings and are meant for interpreting the arrows depicting the variables in the plot)

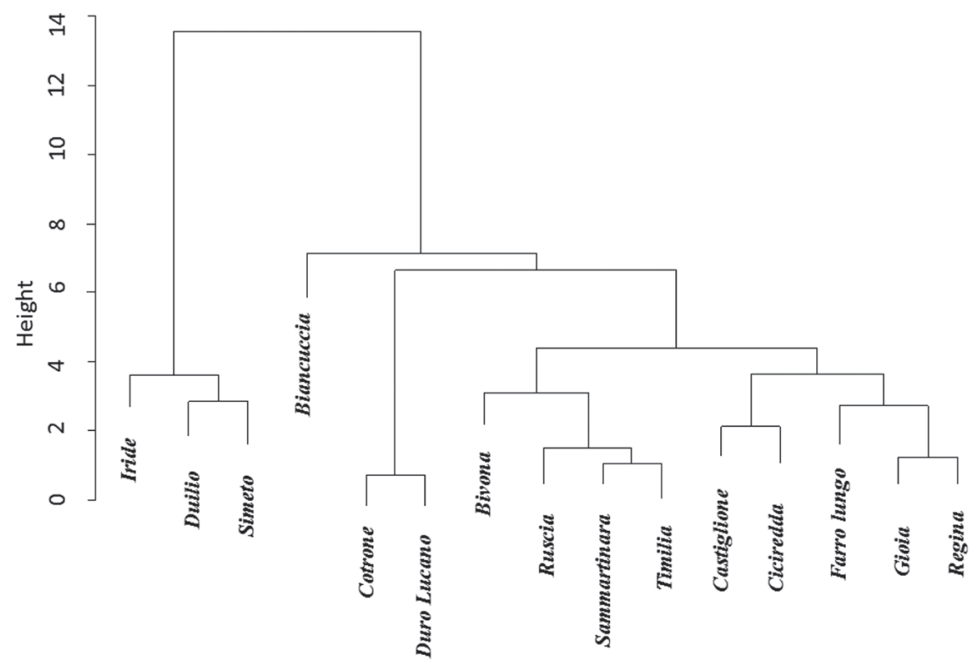

Figure 4. Dendrogram of the cluster analysis based on influence of the concentrations of Fe, $\mathrm{Zn}$ and $\mathrm{Mn}$ in the three years period 
principal component is influenced by iron concentration of $2013(\mathrm{Fe} 13=0.52)$, zinc of $2012(Z n 12=0.47)$ and manganese 2013 and $2014($ Mn13 $=-0.41, M n 14=-0.34)$.

The resulting cluster analysis, carried out according to the Ward's method, produced a dendrogram (Fig. 4) distinguishing, at the linkage distance of 8, the branch dedicated to modern varieties from the group of the Sicilian landraces within which the Biancuccia landrace is further distinguishable. Again, the silhouette width identified two clusters as the most probable estimate (Table 2, righ column) even in this case that is based on Fe, $\mathrm{Mn}$ and $\mathrm{Zn}$ concentrations only.

\section{Discussion}

Between old Sicilian landraces and modern cultivars substantial variation in nutrient seed concentrations can be found. In particular, with reference to N, P and K, their concentrations were higher in Sicilian landraces than in modern cultivars (Table 1). On average, Sicilian landraces showed grain-Fe concentration increased by $32 \%$, grain-Zn by $21 \%$, grain-Mn varied of $38 \%$ compared to modern cultivars ( $\mathrm{Cu}$ was the only element showing significant reduction). Such microelement concentrations are in line or in greater degree, at varying of element bioavailability in soil (Giacalone et al. 2005), with those available in literature. A comparative work on $\mathrm{Fe}$ and $\mathrm{Zn}$ concentrations in Iranian landraces and commercial varieties (Heidari et al. 2016) shows Fe concentration in landraces ranging from 24.9 to $66.5\left(\mathrm{mg} \mathrm{kg}^{-1}\right)$ and $\mathrm{Zn}$ concentration from 18.7 to 38.7 , while in commercial cultivars Fe varied between 38.9 and $54.9 \mathrm{mg} \mathrm{kg}^{-1}$ while $\mathrm{Zn}$ ranged from 12.4 to $27.2 \mathrm{mg}$ $\mathrm{kg}^{-1}$. Wang et al. (2016), who studied the wheat yield responses to manure compost application in North China in a three years experiment (2011-2013), in 2012 and 2013 recorded average values of 25.6 and $19.6 \mathrm{mg} \mathrm{kg}^{-1}$ for Fe, 12.8 and $13.4 \mathrm{mg} \mathrm{kg}^{-1}$ for Zn, 3.3 and $3.6 \mathrm{mg} \mathrm{kg}^{-1}$ for $\mathrm{Cu}$ and $31.7-32.8 \mathrm{mg} \mathrm{kg}^{-1}$ for $\mathrm{Mn}$. The range $41.4-67.7 \mathrm{mg} \mathrm{kg}^{-1}$ of Fe concentration was reported by Badakhshan et al. (2013). In a study focusing different wheat cropping systems and fertilizer applications, iron and zinc concentrations in grains were found to vary between 24.7 and $26.2 \mathrm{mg} \mathrm{kg}^{-1}$ and between 16.0 and $19.2 \mathrm{mg} \mathrm{kg}^{-1}$, respectively (Wozniak and Makarski 2013). Distelfeld et al. (2007) reported iron and zinc to range from 47.5 to $60 \mathrm{mg} \mathrm{kg}^{-1}$ and from 32.3 to $44.2 \mathrm{mg} \mathrm{kg}^{-1}$ in wheat grain. Other studies also showed that $\mathrm{Zn}$ concentration in durum wheat could range from 20 to $30 \mathrm{mg}$ $\mathrm{kg}^{-1}$ and from 5 to $12 \mathrm{mg} \mathrm{kg}^{-1}$ at varying of soil Zn content (Cakmak et al. 2000).

The output of the PCA provided more information about the differences between the two groups of durum wheat populations. In the biplot of Fig. 1 the distance between the area where the three varieties (Iride, Duilio and Simeto) are allocated and the area where the studied landraces are grouped confirms the differences between these populations showing how, besides the microelements vectors expressing great influence (Fe, $\mathrm{Zn}$ and $\mathrm{Mn}$ ), the influence of $\mathrm{Sr}$ and macro elements is strong as well, being such vectors mainly related to the $1^{\text {st }}$ principal component (that accounts for $47.6 \%$ of explained variance). Moreover, in the biplot of Fig. 3 (obtained processing the data related to elements that the previous processing pointed out to be the most influencing ones) it can be observed that modern varieties are grouped separately. In this case Fe and Mn concentrations are those 
discriminating the most among landraces pointing out specific peculiarities (e.g. Biancuccia).

Comparing caryopsis micronutrient concentrations in modern durum wheat varieties and Sicilian landraces confirmed the wide genetic variability observable between the two groups of genotypes. In particular, Sicilian landraces showed higher concentrations of N, $\mathrm{P}, \mathrm{K}, \mathrm{Fe}, \mathrm{Zn}, \mathrm{Mn}$ and Sr. According to the multivariate analysis, micronutrient concentration was also found to have a discriminating role between the two groups of genotypes. Sicilian ancient durum wheat landraces can be therefore considered as a viable source of genetic diversity for increasing micronutrients density in seeds of modern wheat varieties thanks to genetic biofortification programs.

\section{Acknowledgements}

The authors are grateful to the PON01_01145 "ISCOCEM" Project for the financial support. The authors also aknowledge Mr. Elia Premoli, for the valuable help provided in organizing the data set.

\section{References}

Altieri, M.A. 2004. Linking ecologists and traditional farmers in the search for sustainable agriculture. Front. Ecol. Environ. 2:35-42.

AOAC 2010. Official Method 960.52-1961: Microchemical Determination of Nitrogen. Association of Official Analytical Chemists Washington D.C., USA.

Badakhshan, H., Moradi, N., Mohammadzadeh, H., Zakeri, M.R. 2013. Genetic variability analysis of grains $\mathrm{Fe}, \mathrm{Zn}$ and beta-carotene concentration of prevalent wheat varieties in Iran. Int. J. Agr. Crop. Sci. 6:57-62.

Boggini, G., Palumbo, M., Calcagno, F. 1990. Characterization and utilization of Sicilian landraces of durum wheat in breeding programmes. In: Srivastava, J.P., Damania, A.B. (eds), Wheat Genetic Resources: Meeting Diverse Needs. J. Wiley and Sons. Chichester, UK. pp. 223-234.

Cakmak, I., Ozkan, H., Braun, H.J., Welch, R.M., Romheld, V. 2000. Zinc and iron concentrations in seeds of wild, primitive and modern wheats. Food Nutr. Bull. 21:401-403.

Cakmak, I., Pfeiffer, W.H., McClafferty, B. 2010. Biofortification of durum wheat with zinc and iron. Cereal Chem. 87:10-20.

Dallman, P.R. 1987. Iron deficiency and the immune response. Am. J. Clin. Nutr. 46:329-334.

De Vita, P., Mastrangelo, A.M., Matteu, L., Mazzucotelli, E., Virzì, N., Palumbo, M., Lo Storto, M., Rizza, F., Cattivelli, L. 2010. Genetic improvement effects on yield stability in durum wheat genotypes grown in Italy. Field Crops Res. 119:68-77.

Distelfeld, A., Cacmak, I., Peleg, Z., Ozturk, L., Yazici, A.M., Budak, H., Saranga, Y., Fahima, T. 2007. Multiple QTL-effects of wheat Gpc-B1 locus on grain protein and micronutrient concentration. Physiol. Plant. 129:635-643.

Gallo, G., Lo Bianco, M., Bognanni, R., Saimbene, G., Orlando, A., Grillo, O., Saccone, R., Venora, G. 2010. Durum wheat bread: Old Sicilian varieties and improved ones. J. Agr. Sci. Tech. 4:10-17.

Giacalone, A., Gianguzza, A., Orecchio, S., Piazzese, D., Dongarrà, G., Sciarrino, S., Varrica, D. 2005. Metals distribution in the organic and inorganic fractions of soil: a case study on soils from Sicily. Chem. Spec. Bioavailab. 17:83-93.

Golden, M.H.N. 2004. Malnutrition. In: Guandalini, S. (ed.), Textbook of Pediatric Gastroenterology and Nutrition. Taylor \& Francis. London, UK. 
Gomez-Becerra, H.F., Erdem, H., Yazici, A., Tutus, Y., Torun, B., Ozturk, L., Cakmak, I. 2010a. Grain concentrations of protein and mineral nutrients in a large collection of spelt wheat grown under different environments. J. Cereal Sci. 52:342-349.

Gomez-Becerra, H.F., Yazici, A., Ozturk, L., Budak, H., Peleg, Z., Morgounov, A., Fahima, T., Saranga, Y., Cakmak, I. 2010b. Genetic variation and environment stability of grain mineral nutrient concentrations in Triticum dicoccoides under five environments. Euphytica 171:39-52.

Heidari, B., Padash, S., Dadkhodaie, A. 2016. Variations in micronutrients, bread quality and agronomic traits of wheat landrace varieties and commercial cultivars. Aust. J. Crop. Sci. 10:377-384.

Hercberg, S., Galan, P., Dupin, H. 1987. Iron defciency in Africa. World Rev. Nutr. Diet. 54:201-236.

IFPRI - International Food Policy Research Institute. 2014. Global Hunger Index. The Challenge of Hidden Hunger. http://www.ifpri.org [July 2015].

Lafiandra, D., Riccardi, G., Shewry, P.R. 2014. Improving cereal grain carbohydrates for diet and health. J. Cereal Sci. 59:312-326.

Lowe, N.M., Fekete, K., Decsi, T. 2009. Methods of assessment of zinc status in humans: a systematic review. Eur. J. Clin. Nutr. 89:2040S-2051S.

Lozoff, B., Jimenez, E., Xolf, A.W. 1991. Long term development outcome of infants with iron deficiency. New Eng. J. Med. 325:687-694.

Mastromatteo, M., Danza, A., Lecce, L., Spinelli, S., Lampignano, V., Laverse, J., Conto, F., Del Nobile, M.A. 2014. Effect of durum wheat varieties on bread quality. Int. J. Food Sci. Tech. 49:72-81.

Nishi, Y. 1996. Zinc and growth. J. Am. Coll. Nutr. 15:340-344.

Padalino, L., Mastromatteo, M., Lecce, L., Spinelli, S., Contò, F., Del Nobile, M.A. 2014. Effect of durum wheat cultivars on physico-chemical and sensory properties of spaghetti. J. Sci. Food. Agric. 94:2196-2204.

Palumbo, M., Blangiforti, S., Cambrea, M., Gallo, G., Licciardello, S., Spina, A. 2008. Sicilian durum wheat landraces for production of traditional breads. Proc. Int. Durum Wheat Symposium "From Seed to Pasta: The Durum Wheat Chain. Bologna, Italy. pp. 132-132.

Palumbo, M., Cambrea, M., Licciardello, S., Pandolfo, A., Pesce, A., Platania, A., Roccasalva, D., Russo, M., Sciacca, F., Spina, A., Virzì, N. 2013. Collezione di frumento duro in ambiente mediterraneo: germoplasma siciliano e internazionale (Durum wheat collection in Mediterranean environment: Sicilian and international germplasm). In: D'Andrea, F. (ed.), Conservazione biodiversità, gestione banche dati e miglioramento genetico - BIODATI (Conservation of biodiversity, data and gene bank). Rome, Italy. pp. 497-512.

Panatta, G.B. 1997. Cereali e patate (Cereals and potatoes). In: Fidanza, F., Liguori, G. (eds), Nutrizione Umana (Human nutrition). Idelson-Gnocchi. Neaples, Italy. pp. 268-289.

Poblaciones, M.J., Rodrigo, S., Santamaría, O., Chen, Y., McGrath, S.P. 2014. Agronomic selenium biofortification in Triticum durum under Mediterranean conditions: From grain to cooked pasta. Food Chem. 46:378-384.

R Development Core Team 2008. R: a language and environment for statistical computing. R Foundation for Statistical Computing. Vienna, Austria.

Rousseeuw, P.J. 1987. Silhouettes: A graphical aid to the interpretation and validation of cluster analysis. J. Comput. Appl. Math. 20:53-65.

Sandström, B. 1997. Bioavailability of zinc. Eur. J. Clin. Nutr. 51:S17-S19.

Sciacca, F., Blanco, C., Salafia, L., Sgarlata, M.T., Di Silvestro, I., Palumbo, M. 2003. Genetic and biochemical characterization of durum wheat Sicilian landraces. Proc. Tenth Int. Wheat Genetics Symposium. Paestum, Italy. pp. 634-636.

Sciacca, F., Cambrea, M., Licciardello, S., Pesce, A., Romano, E., Spina, A., Virzì, N., Palumbo, M. 2014. Evolution of durum wheat: from Sicilian landraces to improved varieties. Options Méditerranéennes, serie A 110:139-145.

Scrimshaw, N.S. 1984. Functional consequences of iron deficiency in human populations. J. Nutr. Sci. Vitaminol. 30:47-63.

Semenov, M.A., Stratonovitch, P., Alghabari, F., Gooding, M.J. 2014. Adapting wheat in Europe for climate change. J. Cereal Sci. 59:245-256.

Shewry P.R. 2009. Wheat. J. Exp. Bot. 60:1537. 
Shewry, P.R., Halford, N.G. 2002. Cereal seed storage proteins: structures, properties and role in grain utilization. J. Exp. Bot. 53:947-958.

Stewart, C.P., Dewey, K.G., Ashoran, P. 2009. The undernutrition epidemic: an urgent health priority. The Lancet 374:1473.

Thomas, M., Demeulenaerev, E., Dawsonv, J.C., Rehman Khan, A., Galic, N., Jouanne-Pin, S., Remoué, C., Bonneuil, C., Goldringer, I. 2012. On-farm dynamic management of genetic diversity: the impact of seed diffusions and seed saving practices on a population-variety of bread wheat. Evol. Appl. 5:779-795.

Todeschini, R. 1988. Introduzione alla Chemiometria (Introduction to Chemometrics). EdiSES. Naples, Italy. pp. $37-79$.

Velu, G., Ortiz-Monasterio, I., Cakmak, I., Hao, Y., Singh, R.P. 2014. Biofortification strategies to increase grain zinc and iron concentrations in wheat. J. Cereal Sci. 59:365-372.

Wang, F., Wang, Z., Kou, C., Ma, Z., Zhao, D. 2016. Responses of wheat yield, macro- and micro-nutrients, and heavy metals in soil and wheat following the application of manure compost on the North China plain. PLoS ONE 11: e0146453. https://doi.org/10.1371/journal.pone.0146453

Welch, R.M., Graham, R.D. 1999. A new paradigm for world agriculture: meeting human needs. Productive, sustainable, nutritious. Field Crops Res. 60:1-10.

Wozniak, A., Makarski, B. 2013. Content of minerals, total protein and wet gluten in grain of spring wheat depending on cropping systems. J. Elem. 18:297-305.

Xu, Y., An, D., Li, H., Xu, H. 2011. Review: Breeding wheat for enhanced micronutrients. Can. J. Plant Sci. 91:231-237.

Zhao, F.J., Su, Y.H., Dunham, S.J., Rakszegi, M., Bedo, Z., McGrath, S.P., Shewry, P.R. 2009. Variation in mineral micronutrient concentrations in grain of wheat lines of diverse origin. J. Cereal Sci. 49:290-295. 